\title{
A incompletude das coisas e dos seres
}

\author{
The incompleteness of things and beings
}

\author{
Valdemar Valente Junior
}

A condição improvável do que corresponde a cada um, diante das situações impostas pelo cotidiano, induz à crença de que se marcha inevitavelmente em direção ao nada, quando se pensa ter chegado, percebendo-se, em seguida, que já é hora de voltar de algum lugar que simplesmente não existe. A ilusão da existência concorre para que se deem aos acontecimentos mais comezinhos a dimensão épica de feito inenarrável. A pelada do fim de semana pode parecer um clássico do futebol internacional e a happy hour com cerveja e churrasco, um evento da maior importância no jet set. Vive-se no subúrbio acanhado a dimensão cósmica de que a cidade é um planeta único dentro do sistema solar. Desse modo, a contemporaneidade poder ser traduzida como hipérbole de situações que avançam ou recuam na direção do bem e do mal, uma vez que o fim da história parece também ter decretado o fim do homem. Daí decorre a urgência de se viver tudo a um só tempo, potencializando, na perspectiva do presente, a negação do passado, a partir da velocidade das ações que fazem com que o futuro seja aqui e agora. A essa discussão pode ser acrescida a dimensão do que se faz perceber em Ferrugem, coletânea de contos de Marcelo Moutinho que busca viabilizar a possibilidade de se poder encontrar o fio do tempo, rebobinando o carretel de existências quase sempre precárias, mas que devem ser percorridas como forma de se encontrar a outra extremidade do que parece perdido.

Em vista de seu título, que dá conta do processo de oxidação do aço, além da ilustração da capa, onde se vê uma broca a perfurar uma superfície envolta em limalha, Ferrugem evidencia em seus treze contos a situação de incompletude das coisas e dos seres, em vista do que se mostra em sua feição inacabada, a partir de personagens que se expõem em sua condição vulnerável. Os atares e desatares de situações que se antagonizam concorrem para que essas personagens se situem sempre na condição de quem busca incessantemente dar conta de demandas reprimidas, que têm pressa em romper com a estagnação de tudo quanto as pressiona. Assim, o lugar que cada uma delas ocupa decorre da insatisfação diante de um contexto de promessas fraudadas, quando as situações desviantes concorrem para que nada possa dar certo. No entanto, se faz preciso reverter essa expectativa, no sentido de tornar realizável o que se apresenta no plano do imponderável, mesmo que a isso se imponha a necessidade de se recolherem os destroços do que sobrou para poder recomeçar. Assim, as atitudes justificam-se na forma com que as personagens encaram suas estranhezas, em vista dos absurdos de um cotidiano que oscila, no que se refere à dimensão de realidade que habita a narrativa.

\footnotetext{
1 Mestre em Ciência da literatura pela UFRJ. Doutor em Ciência da Literatura pela UFRJ. Pós Doutor em Literatura Brasileira pela UERJ. Autor de Dispersa sequência: ensaios de literatura brasileira (2014); O mel do engenho, o fel da palavra: desconstrução da ideologia na poesia satírica de Gregório de Matos (2015); Entre a cidade e o campo: Mário de Andrade e a música popular (2016); O mundo às avessas e outros ensaio (2017); Espaços da exclusão na literatura brasileira (a sair). Universidade Castelo Branco (UCB) e Faculdade Paraíso (FAP). ORCID: http://orcid.org/oooo-0001-6190-989X. E-mail: valdemarvalente@gmail.com
} 
Por isso, a sequência dos episódios dá conta de situações que se inserem no plano do improvável, quando Rodrigo faz amor com a boneca de sua irmã, a partir da descoberta do sexo com um brinquedo, em “Xodó”. Daí a tensão erógena do adolescente encontrar uma alternativa que foge à regra da descoberta mútua entre os corpos. De modo oposto, Custódio deixa passar a oportunidade de estabelecer um relacionamento com Camila, passageira do mesmo ônibus, ainda que sob a intermediação de Conceição, a cobradora que lhe dá conselhos de como se aproximar de quem se diz apaixonado. Em "362" verifica-se a pressa de viver e o desencontro no dia a dia das grandes cidades, resultando a demora na declaração amorosa em frustração, uma vez que, ao mudar de emprego, a moça deixa de viajar nessa linha de ônibus. O desencontro entre o desejo e sua realização também se faz presente em "Gandula", quando o sonho frustrado de João em ser meia-atacante do Vila Rica o faz aceitar o convite para trabalhar nos fins de semana no Maracanã, repondo em jogo as bolas que saem pelas quatro linhas do gramado como única possibilidade de não permanecer afastado do futebol.

Esses desencontros aliam-se às surpresas que o inesperado reserva a cada instante, quando a vontade de recomeçar, depois de trinta anos, esbarra no silêncio e na ausência. Assim, "As praias desertas" induz às perdas e transformações que o tempo impõe como registros inexoráveis do que se transforma em passado, não havendo como se recuperar o que se dispersa. Em sentido contrário, uma surpresa pode vir a acontecer, quando parte do letreiro de uma chapelaria invade a sala, trazida pela tempestade. Em "Caiu uma estrela na minha sala", a súbita queda de um corpo celeste traduz a forma através da qual cada um recebe os efeitos de tudo quanto lhe possa suceder, além da carga simbólica de sua representação. A esse sentido de representação agrega-se a história amorosa que chega ao fim tendo como trilha sonora uma canção dos Beatles. O conto "Something" faz referência a um sucesso da banda inglesa que acalentou muitas paixões, mas tem como tema a separação. O lugar do desamor, portanto, faz com que o reencontro em uma festa seja meramente trivial, seguindo a formalidade civilizada.

O desejo encontra em Ferrugem um espaço que tem como referência a vontade que obedece a instintos e se confunde com a obsessão. Isso ocorre em "Rei", quando o cantor de boate que imita Roberto Carlos, mesmo diante da obsolescência de caracterizar-se como o famoso cantor, leva seu sonho até o final. Para que isso tenha lugar, sacrifica suas parcas economias, realizando na boate Pussy House o espetáculo de sua vida, para em seguida retornar de ônibus à casa onde mora e recomeçar, na noite seguinte, sua rotina de cantor. Assim, a realização subentende condições mínimas e sacrifícios máximos, a exemplo de "Nomes de Deus", em que um engenheiro, que passa a ser conhecido com Divino, abdica da profissão para catar nos toneis de lixo, nos fins de semana, e nos lixões, durante os demais dias, em disputa com urubus, porcos e ratos. A sua missão consiste em resgatar do desperdício, papeis e registros que tragam os diferentes nomes de Deus. Daí o significado das coisas mais simples assumir uma força expressiva capaz de transformar os objetos, dando-lhes uma dimensão superior que potencializa a sua razão de ser. O oposto a isso verifica-se em "Jantar a dois", quando o encontro do casal em um restaurante apresenta-se esvaziado de significado, diante da celebração de um aniversário, o que somente se revela ao final do conto.

A transformação da realidade no que poderia ter sido concorre para que em "Domingo no Maracanã" Bia, em companhia dos pais, ao visitar o estádio em obras de remodelação, descubra entre os tapumes uma fenda que a faz enxergar o gramado, por onde imagina histórias com finais diferentes. Assim, o goleiro Barbosa defende o chute do ponta-direita Ghiggia e o ponta-esquerda Ado marca o gol de pênalti no goleiro Rafael, sendo a Seleção Brasileira campeã mundial, em 1950, e o Bangu campeão brasileiro, em 1985. Do mesmo modo, em "Sauna", o Professor Monteiro, um homem bem-casado, frequentador da Sauna 69, na Rua Correia Dutra, no Catete, interrompe a história do que poderia ter ocorrido ao encontrar um aluno, fugindo do local 
onde busca sentir-se atraído pelos corpos de outros homens. Outra vez a fuga se impõe à ordem das coisas para as quais não há solução ou resposta. Em "Três apitos", a caixa de supermercado, portadora do vírus HIV, reencontra o antigo namorado, que não se contaminara, com quem pensara em casar e constituir família, ao lado da esposa que espera por um filho. Por sua vez, a insatisfação se faz presente em "Dezembros", quando um ajudante de cozinha aposentado, que trabalhara na Rádio Nacional e servira aos grandes astros da emissora, oculta sua condição de subalterno ao criar para o neto a ideia de que fora um cantor.

A reunião desse variado número de personagens à margem do que representa uma suposta condição de normalidade responde às indagações da contemporaneidade como termo da relação do homem com situações diante das quais não consegue sentir-se confortável. Os desencontros que marcam a trajetória das personagens de Ferrugem sugerem o esgotamento relativo às situações para as quais não parece haver uma alternativa que se mostre compensatória, diante do impasse que representa o lugar incomum que cada uma delas ocupa. A relação com os deslizes e obsessões de que são reféns transforma os níveis de identidade que marcam os seus respectivos lugares no mundo. As crises que debilitam o convívio induzem ao caos dos conflitos o relacionamento que cada personagem trava consigo. Desse modo, Ferrugem apresenta-se como possibilidade de reflexão acerca dos desníveis que não têm como serem revistos em sua condição refratária. Por isso, viabiliza a discussão que envolve os dramas particulares de quem não possui meios capazes de superá-los, no plano da ficção como uma extensão da realidade, por não haver a cura prometida para as dores e aflições que atingem a condição humana.

\section{Referências}

MOUTINHO, Marcelo. Ferrugem. Rio de Janeiro: Record, 2017. $160 \mathrm{p}$.

Recebido em: 3/6/2018.

Aprovado em: 16/8/2018.

\section{Valdemar Valente Junior}

Universidade Castelo Branco (UCB) e Faculdade Paraíso (FAP)

Orcid: http://orcid.org/oooo-0001-6190-989X

E-mail: valdemarvalente@gmail.com

Endereço de correspondência: Rua das Dálias, 66 apto 105 - Vila Valqueire. Rio de Janeiro - RJ. CEP: 21330-740 